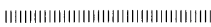

\title{
農薬の内分泌攪乱作用検出のためのアプローチ
}

\author{
青 山 博 昭* \\ (財)残留農薬研究所 毒性第一部 生殖毒性研究室
}

(平成 13 年 6 月 20 日受理)

\section{An Approach for Predicting Endocrine Disrupting Activities of Pesticides}

\author{
Hiroaki AoYAmA \\ Laboratory of Reproductive Toxicology, Toxicology Division I, Institute of \\ Environmental Toxicology, Ibaraki 303-0043, Japan
}

Key words: エストロゲン様作用 (estrogenic effects), 抗アンドロゲン様作用 (anti-androgenic effects), 内分泌活性物質 (endocrine active compounds)，スクリーニング試験 (screening assay), 確定試験 (definitive study)，2 世代繁殖試験（two-generation reproductive toxicity study).

\section{は じめに}

我々は, 農薬の生殖・発生毒性検出を主たる業務として いる関係上，農薬の内分泌活性や内分泌攪乱作用に基づく と考之られる生殖毒性との関わりも比較的長い. 本稿では, 我々の研究室における農薬のヒトに対する内分泌攪乱作用 検出（あるいは予測）のための戦略を簡単に説明する。本 稿では内分泌攪乱作用の検討を含む安全性評価の実際を解 説することに主眼を置くため, 内分泌攪乱物質 (Endocrine Disruptors，EDsまたは Endocrine Disrupting Chemicals, EDCs)の定義や作用機序の解説については，我々の戦略を 説明するための最小限の記載に止める。 それらの詳細につ いては，OECD や米国 EPA の関連文書あるいはそれらの 解説を参照されたい ${ }^{1-5)}$. また，この分野における最新の科 学的知見を紹介することもまた本稿の目的ではないため, これらに関する論文についても多くを引用しない，読者の 興味に従って, それぞれの分野の専門誌に掲載された個々 の論文を参照されたい。

\section{1. 内分泌晎乱物質と内分泌活性物質}

内分泌攪乱物質の定義はいくつも存在するが，信頼でき る機関が提唱する定義は，細かな表現の違いを除けば概ね

\footnotetext{
${ }^{*} \bar{\top}$ 303-0043 水海道市内守谷町 4321
}

共通している。それらによれば，内分泌攪乱物質とは「内 分泌系の形態あるいは機能を変化させ，結果として動物に 悪影響を及ぼす化学物質もしくはそれらの混合物」を指す。 また，これらの悪影響は「特別な処置を施さない(intact な) 個体を用いた実験・観察により，個体またはそれ以上（集 団，亜集団）のレベルで確認されなければならない」とす る点についても, 今や世界的に共通した認識となっている.

一般に，ある化学物質が内分泌活性を持つか否かの判定 は，それ程困難ではない，例之ば，ホルモン受容体と化学 物質との親和性を受容体結合試験 (Receptor Binding Assay)で直接測定したり，化学物質をある種のホルモンに 感受性を示す細胞に暴露して反応（例之ば増殖活性）を調 べたりすることにより，化学物質が天然ホルモンと類似し た作用を持つか否かを容易に判断することができる．しか し, 上述の例の如く in vitro である種の化学物質に天然木 ルモンと類似した作用が検出されたとしても，その活性は 極めて低い場合もあり，そのような化合物については in vivo 実験で同様の作用を確認することはしばしば困難であ る.さらに，仮に卵巣あるいは精巣などの内分泌器官を摘 出してホルモン産生能を奪った動物を用いた実験では陽性 反応が得られたとしても，このような処置を施さない （intact な）動物を用いた実験で悪影響を検出することは容 易ではない.

最近では，内分泌系に対する何らかの作用は認められる 
ものの，それらの作用に基づく悪影響が引き起こされるか 否かの確認はなされていないような化学物質に対して, 内 分泌活性物質 (Endocrine Active Compounds, EACs) とい う用語を当てはめる事例がしばしば見受けられる。本稿に おいても, 無処置の個体に何らかの悪影響（生殖毒性や発 癌性など）が引き起こされることが確認された化学物質に ついては「内分泌攪乱物質」, in vitro 試験を含む何らかの 実験で内分泌系に対する何らかの関与が認められるもの の, それが悪影響であると断定できない場合は「内分泌活 性物質」と記載する。

\section{2. 内分泌㩭乱物質検出のための 一般的なアプローチ}

今までに人類が作り上げてきた人工的化学物質の数は, 10 万種類を越えると言われている。したがって，もしもこ れらの化学物質すべてについて内分泌攪乱性の有無を調べ るとすると，膨大な時間と労力が必要となる．例えば，現 在のところ内分泌攪乱作用による生殖毒性をもっとも確実 に検出できると期待されているラットを用いた 2 世代繁殖 試験は, どんなに急いでもその実施に約 1 年を要する. 仮 にこの手法で化学物質の生殖毒性を評価することができる 世界中の研究室が協力して年間 100 試験を実施するとして も，すべての化合物を調べ終わるまでに 1000 年という単位 の時間がかかる. 無論, その間にも新たな化学物質が合成 され続けるであろうから，当面のところ残念ながらこのよ うな戦略は成り立たない。そこで，既存のデー夕を利用し て何らかの方法で検查対象とすべき化学物質を選別し, 優 先順位の高い化合物から順に試験を実施する必要が生ず る.

現在提唱されている一般的な戦略を，図 1 に示す。まず, それぞれの物質ごとに生産量や毒性に関するデー夕を整理 し，優先的に検査対象とすべき物質を選抜する（Priority setting)。この過程では, 生産量の多い物質, 既存のデー夕 や構造活性相関 (QSAR) による解析結果から, 毒性 (内分 泌攪乱性)の懸念される物質に高い優先順位が付けられる。 この段階で除外された物質については，現在の科学水準で は直ちに確定試験を実施する必要はないと判断されたので あって，内分泌攪乱性がないと結論されたわけではない。 したがって，科学の進歩により将来新たな疑いが生じた場 合は，その時点で次のステップ（スクリーニングあるいは 確定試験）に進むこととなる。

スクリーニングを実施すべきと判断された物質について は，表 1 に示すような方法にしたがって，調べるべき作用 の有無について順次検討する.表 1 に掲げた試験法のうち, いくつかの方法については既に国際的な検証試験が進んで

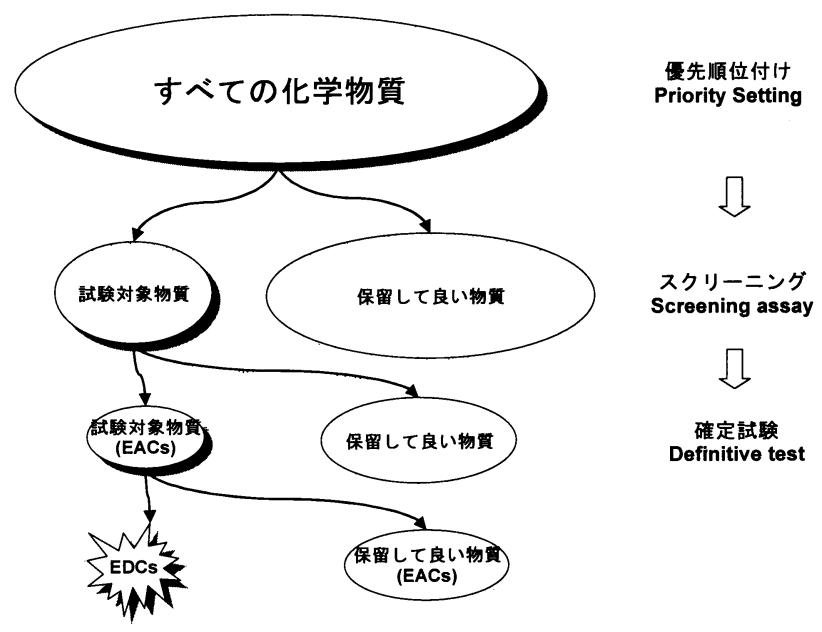

図 1 化学物質の内分泌攪乱性を調べるための戦略 すべての化学物質について直ちに確定試験を実施すること は事実上不可能なので, 優先順位付け, スクリーニングによ ク化合物を順次子るいにかけ，確定試験を実施すべき化合 物を絞り込む. 内分泌攪乱性の有無については, 確定試験の 結果に基づいて最終判断を下す.

表 1 主なスクリーニング法

\begin{tabular}{lll}
\hline 検査対象 & In vitro 試験 & In vivo 試験 \\
\hline エストロゲン作動系 & ER receptor binding assay & Uterotrophic assay \\
& $\begin{array}{l}\text { Reporter gene assay } \\
\text { E-screen }\end{array}$ & \\
アンドロゲン作動系 & AR receptor binding assay & Hershberger assay \\
& Reporter gene assay & Frog metamorphosis assay \\
甲状腺ホルモン作動系 & Reporter gene assay & Enhanced TG 407 \\
ステロイド代謝・合成系 & Steroidgenesis assay with minced testis & Enhanced TG 407 \\
& Placental aromatase assay & \\
\hline
\end{tabular}

スクリーニングとしてどのような方法を組み合わせるかについては，様々な考え方がある，例えば，性ホルモン（エストロゲ ンおよびアンドロゲン）受容体に対する親和性の有無に着目して最小限の労力で化学物質を振り分けたいのであれば，エスト ロゲンおよびアンドロゲン受容体を用いた受容体結合試験のみから大きく分類することも可能である，ただし，見落としの危 険性も同時に高くなる. 
表 2 動物の生殖に及ぼす影響を評価する主な確定試験法

\begin{tabular}{lll}
\hline 調ベる影響 & 試験法 & 試験に使用する動物種 \\
\hline ヒトに対する影響 & 2 世代繁殖試験 & ラット \\
& 発生毒性 (催奇形性) $)$ 試験 & ラット/ウサギ/マウス \\
& 1 世代繁殖試験 & ラット/マウス (?) \\
野生生物に対する影響 & 鳥類繁殖試験 (1 世代/2 世代) & 日本ウズラ/Bobwhite quail \\
& 魚類の Life cycle test & メ゙カ/Fathead minnow/Zebra fish \\
& 再生類の生殖・発生毒性試験 & アフリカツメガエル \\
& 甲殻類の Life cycle test & America mysis $(ア ミ) ~$ \\
\hline
\end{tabular}

おり ${ }^{6)}$, 今後は検証試験による有効性の確認を経て, 世界的 に広く利用されるようになると考えられる。これらの試験 法の詳細については，文献を参照されたい ${ }^{1,2,7)}$.

現在のところ, 化学物質のエストロゲン様または抗アン ドロゲン様作用が注目を集めていることから，エストロゲ ンまたはアンドロゲン受容体との親和性の有無をin vitro で調べた実験結果の報告が数多くみられる。しかし, 前述 した如く in vitro で検出された受容体との弱い親和性が in vivo では検出されない場合もしばしばあるため, in vitro 試 験の結果だけに基づく優先順位付けを実施すると, 確定試 験を実施すべき化合物の絞り込みが不十分となる可能性が 高い。このような事態を回避するためには, in vivo 試験と してUterotrophic assay (子宮肥大試験) や Hershberger assay（雄の副生殖器肥大試験）を同時に実施することによ ク, 化学物質の作用強度をより正確に予測することが肝要 であろう。

一方，エストロゲンまたはアンドロゲン受容体との親和 性が陰性であるにもかかわらず，生体におけるステロイド ホルモンの合成や代謝に拘わる酵素の活性を修飾すること により，二次的にこれらのホルモン作動系に影響を及ぼす 化合物も存在することが知られている。 また，甲状腺ホル モン作動系に影響を及ぼす化合物についても，生後の知能 あるいは行動発達との関連から, このような作用の毒性学 的意義を明らかにする必要性が指摘されている．したがっ て, 確定試験を実施すべき化学物質を選抜するためのスク リーニングを実施する際には，表に挙げた試験法を組み合 わせて実施することにより，これらの作用を持つ化合物を 漏れなく検出するよう努力することが望まれる.

表に揭げた一連のスクリーニング試験の結果がすべて陰 性であった場合は, その化合物を保留扱いとして, 確定試 験の対象からひとまず除外する. しかし, 現在提唱されて いるスクリーニング試験ではあらゆる内分泌活性が検出で きるわけではないことから，この段階で除外された物質が 内分泌攪乱性を有しないと結論されるわけではない。この 段階で陰性結果の得られた化合物は，あくまで現時点では これ以上の試験の実施を保留しても良いと判断されたに過 ぎないことを忘れてはならない。
スクリーニング試験で陽性結果が得られた化合物につい ては, in vivo 確定試験を実施して, 内分泌鹠乱性の有無を 最終的に評価することとなる，有効性が期待されている試 験法を, 表 2 に示す. 表に示した方法は, いずれも化学物 質の内分泌攪乱性を検出するために設計されたものではな い.しかし，これらの試験法は，作用機序の如何を問わず 生殖毒性を鋭敏に検出することができるように設計された ものであることから，適切な検査項目を適宜追加すること により，化学物質の内分泌攪乱作用に基づく生殖毒性を検 出することができるものと考えられている。これらの試験 と共に発癌性試験や発達神経毒性試験などを組み合わせて 実施し, さらには暴露評価を加えることにより, 現在の科 学的知見に基づいたリスク評価がなされる.

内分泌攪乱物質の極低用量影響については, 現在のとこ ろその存在の有無すら科学的に定まらない(この問題に関 する最新の知見は, 文献8)を参照されたい). したがって, これらの問題が未解決のまま実施される現在のリスク評価 は，残念ながら必ずしも完全であるとは言い切れない。し かし，内分泌攪乱物質の作用について未知の部分が残され ているとはいえ, それらの高用量影響については現在の方 法でも検出（予測）することが可能である. また，リスク 評価は本来科学の進歩に伴って繰り返し実施されるべきも のであると考えられることから, 現時点で最新の科学的知 見に基づいたリスク評価を早急に実施することが我々の務 めであると考えられる。

\section{3. 農薬の内分泌筧乱作用検出法}

我が国では，少なくとも食用農薬については登録に際し て催奇形性試験（発生毒性試験）や 2 世代繁殖試験の実施 が義務づけられており, 発癌性についても十分な検討が要 求されている. したがって, 最新のがイドラインに沿って これらの試験が実施してあれば，内分泌攪乱性の有無につ いても最善の方法（現在もっとも有効な確定試験と考えら れている方法）で検查が実施されていると考えられる。し かし, 仮にこれらの試験で何らかの生殖毒性や発癌性が検 出されたとしても，それだけではその作用機序を明らかに することが困難な場合が多い，そこで，そのような農薬に 
ついては，一般化学物質の内分泌攪乱作用を調べる際に優 先順位付けのために実施する各種のスクリーニング試験を 繁殖毒性や発癌性の機序を調べるためのメカニズム解析試 験として用いて, 観察された毒性が内分泌攪乱性に基づく ものか否かを検討することとなる.

我々の研究室における基本的戦略を，図 2 に示す。何ら かの生殖・発生毒性が検出された場合や，あるいはそれら を疑うような変化がみられた場合, それらが被験物質と工 ストロゲンまたはアンドロゲン受容体との相互作用を介し

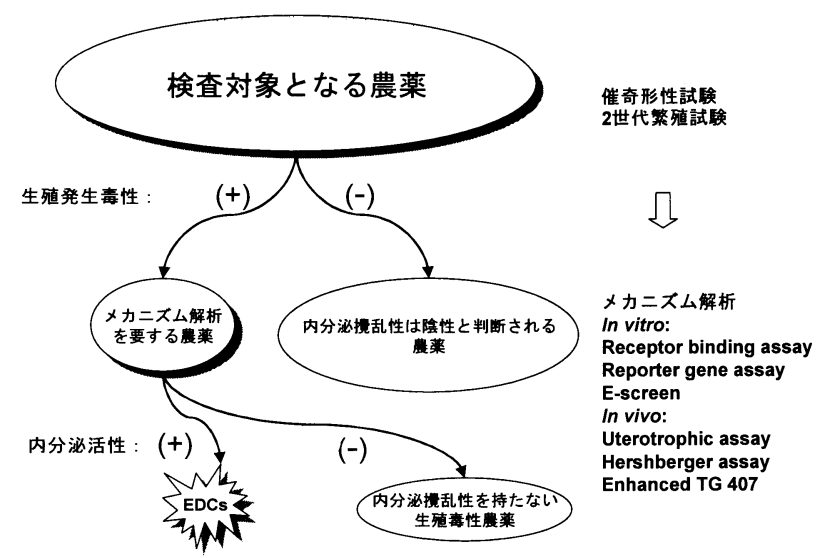

図 2 農薬の内分泌攪乱性を確認する戦略

催奇形性試験や 2 世代繁殖試験で何らかの生殖・発生毒性 がみられた場合に, それらの毒性が内分泌攪乱作用に基づ くものか否かを検討する. て引き起こされたものであるか否かを，まずin vitroの Receptor binding assayまたは Reporter gene assay で調べ る. Reporter gene assayは, ホルモンと農薬を同時に暴露 することにより拮抗作用の有無を調べることができる長所 がある.しかし, 酵母に受容体と応答遺伝子(reporter gene) の两者を導入した系などでは，化学物質の膜透過性が動物 細胞とは異なる場合があることや，そもそも人工的に組み 込んだ応答系では真の作用はみられないとの批判もあっ て，それらの試験系を用いた解析には注意を要する。我々 は, 受容体を発現する七ト由来細胞に応答遺伝子を導入し た采9をを用いて解析を実施している.

これらの in vitroの試験系でアンドロゲン受容体との相 互作用が認められた場合は Hershberger assay を，エストロ ゲン受容体との相互作用が認められた場合には Uterotrophic assayを実施して，in vivoにおける作用の有無を確認 する。一方，被験物質とこれらの受容体との間に相互作用 が認められない場合は, 種々のホルモンの血中濃度の変化 を検出するために指標を追加した補強 28 日間試験（Enhanecd TG407）を実施して，被験物質のステロイドあるい は下垂体ホルモン合成系に対する影響の有無を評価する. 妊娠期間中の母動物では薬物代謝酵素（P450）の活性や血 中の性ホルモン濃度が非妊娠期とは著しく異なるため，場 合によっては妊娠動物を用いて内分泌系の変化を検討する 実験も追加する，細胞増殖試験 (E-screen) は，エストロゲ ン様（あるいは抗エストロゲン様）作用の確認に用いる。

表 3 メトキシクロールのラットにおける繁殖試験：親動物に対する影響

\begin{tabular}{|c|c|c|c|c|c|c|}
\hline \multirow{3}{*}{ 検查項目 } & \multicolumn{3}{|c|}{ P世代親動物 } & \multicolumn{3}{|c|}{ F1世代親動物 } \\
\hline & \multicolumn{3}{|c|}{ 投与用自 (ppm) } & \multicolumn{3}{|c|}{ 投与用量 (ppm) } \\
\hline & 10 & 500 & 1500 & 10 & 500 & 1500 \\
\hline \multicolumn{7}{|l|}{ 親動物に対する一般毒性 } \\
\hline 臨床所見 & 影櫭なし & 影䇺なし & 脱毛 $\uparrow$ & 影短なし & 影短なし & 脱毛 † \\
\hline 体重 & 影锌なし & 1 & $1 t$ & 影竡なし & $\downarrow$ & $\downarrow \downarrow$ \\
\hline 体重増加量 & 影䈉なし & $\downarrow$ & $\downarrow t$ & 影䇺なし & $\downarrow$ & $\frac{t t}{t}$ \\
\hline 摂䁒量 & 影啎なし & $\frac{1}{t}$ & It & 影敏なし & $\downarrow$ & It \\
\hline 藏器重量 : 雄の副生殖器 & 影短なし & 影䇺なし & $\downarrow$ & 影箁なし & 影踫なし & $\downarrow$ \\
\hline 蔵器重量 : 琎の子宮 & 影響なし & 影酃なし & 1 & 影䆄なし & 影稫なし & 影敏なし \\
\hline 剖検所見 & 影䈏なし & 影響なし & 影稫なし & 影箇なし & 影製なし & 影䇺なし \\
\hline \multicolumn{7}{|l|}{ 親動物に対する繁殖畫性 } \\
\hline \multicolumn{7}{|l|}{ 従来からの検查項目 } \\
\hline 交尾率 & 影䈉なし & 影䇺なし & 影響なし & 影啷なし & 影笠なし & 影製なし \\
\hline 妊娠率 & 影箁なし & 影響なし & 影笠なし & 影䇾なし & 影㗼なし & $\downarrow$ \\
\hline 着床数 & 影短なし & $\downarrow$ & $\downarrow$ & 影笠なし & $\downarrow$ & $\downarrow$ \\
\hline 産児数 & 影箁なし & $t$ & $\frac{1}{t}$ & 影䜾なし & $\downarrow$ & $\downarrow$ \\
\hline \multicolumn{7}{|l|}{ 新たに追加した検查項目 } \\
\hline 性成熟 & 一 & 一 & - & 影䈇なし & 影䇾なし & やや遅延 \\
\hline 性周期 & 影霎なし & 影䇺なし & T4 & 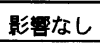 & 4 & 44 \\
\hline 精子数 & 影霓なし & 影敏なし & $\frac{1}{t}$ & 影雷なし & 影䨐なし & $\frac{1}{2}$ \\
\hline 精子運動性 & 影䈉なし & 影䈏なし & 影稫なし & 影霎なし & 影筹なし & 影霎なし \\
\hline 血中ホルモン濃度測定 & 影䇾なし & E2 $\downarrow$ & $E 2 \downarrow$ & - & - & - \\
\hline
\end{tabular}

$\downarrow$ : 減少, $\downarrow$ : 著しく減少, $\uparrow ：$ 増加または延長, $\uparrow \uparrow:$ 著しく増加または延長. 
表 4 メトキシクロールのラットにおける繁殖試験：児動物に対する影響

\begin{tabular}{|c|c|c|c|c|c|c|}
\hline \multirow{3}{*}{ 検査項目 } & \multicolumn{3}{|c|}{ F1児動物 } & \multicolumn{3}{|c|}{ F2児動物 } \\
\hline & \multicolumn{3}{|c|}{ 投与用量 (ppm) } & \multicolumn{3}{|c|}{ 投与用量 (ppm) } \\
\hline & 10 & 500 & 1500 & 10 & 500 & 1500 \\
\hline \multicolumn{7}{|l|}{ 㱜来からの検查項目 } \\
\hline 臨床所見 & 影響なし & 影響なし & 影響なし & 影警なし & 影䇾なし & 影響なし \\
\hline 生存率 & 影㗽なし & 影響なし & 影響なし & 影響なし & 影響なし & 影響なし \\
\hline 体重 & 影響なし & 1 & $1 t$ & 影響なし & 1 & 11 \\
\hline \multicolumn{7}{|l|}{ 新たに追加した検查項目 } \\
\hline 臟器重量 (胸腺重量) & 影饗なし & 影響なし & $t$ & 影響なし & $d t$ & tt \\
\hline 藏器重量（子宮重量） & 影響なし & $\uparrow \uparrow$ & $\uparrow$ & 影響なし & $\uparrow \uparrow$ & $\uparrow \uparrow$ \\
\hline
\end{tabular}

: 減少, $\downarrow$ : 著しく減少, $\uparrow:$ 増加, $\uparrow \uparrow:$ 著しく増加.

いずれの世代においても, 親動物の体重, 体重増加量および捸餌量が, $500 \mathrm{ppm}$ 以上の投与 群で有意に減少した。これらの影響の程度には，明確な用量反応関係が認められた，児動 物に対する毒性は, 親動物の一般毒性が明らかな用量でのみ観察された. 従来からの検査 と新たに追加した検査の間で, 被検物質の繁殖障害作用の検出感度に差はみられなかった.

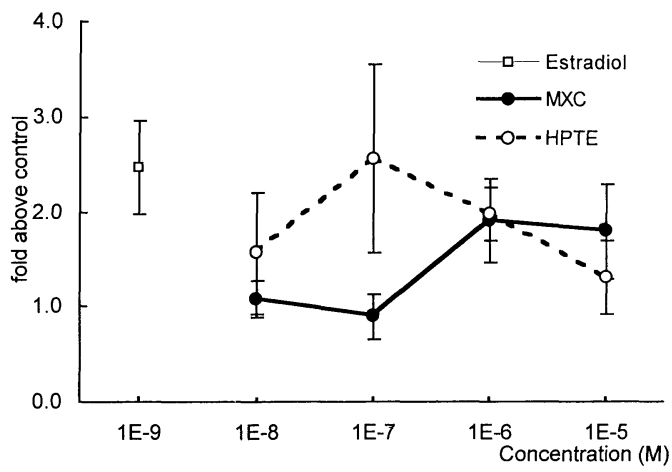

図 3 E-screen の結果

メトキシクロール $(\mathrm{MXC})$ には $10^{-6} \mathrm{M}$ 以上の濃度で MCF7 細胞の増殖活性を増加させる作用があり, この作用は代 謝産物である HPTE でより強く認められる。

これら一連の試験を追加することにより，ヒトに対する 農薬の内分泌かく乱作用に基づく生殖・発生毒性は，概ね 検出できるものと予測している，以下に，これらの戦略の 有効性を確認するために実施したメトキシクロールを用い た一連の実験結果と，同様の方法で p,p'-DDT の内分泌攪 乱作用を検討した結果を簡単に述べる。

メトキシクロールについては，まずラットを用いて最新 の方法による 2 世代繁殖試験を実施したところ，表 3 およ び 4 に示すような種々の生殖毒性が検出された。すなわち, $500 \mathrm{ppm}$ 以上の投与群では, 親動物の体重, 体重増加量およ び搨餌量と児動物の体重が, 用量反応関係を伴って有意に 減少した。また，これらの投与群では着床数や産児数が同 様に有意に低下し，1500 ppm 投与群の F1 世代では妊娠率 の有意な低下も認められた。これらの結果から,メトキシ クロールが繁殖毒性を有することが明らかである.さらに, 雌親動物の性周期に延長がみられたこと, エストロゲンの 血中濃度が低下したこと, 雄親動物の精子数が減少したこ と,および雌離乳児の子宮重量が増加したことなどから，

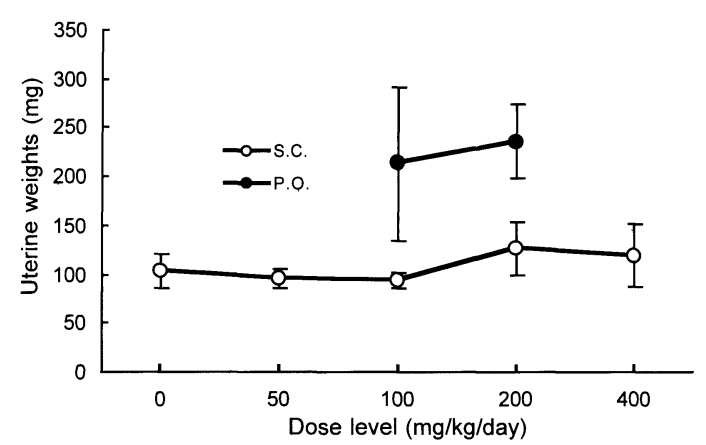

図 4 Uterotrophic assay の結果

$100 \mathrm{mg} / \mathrm{kg}$ 以上の用量のメトキシクロールを卵巣摘出した ラットに経口投与すると，これらの動物の子宮重量を増加 させる作用がある。

メトキシクロールもしくはその代謝産物にはエストロゲン 様作用があることが示唆される。そこで,メトキシクロール とその主たる代謝産物である2,2-bis ( $p$-hydroxyphenyl)1,1,1-trichloroethane (HPTE) について，エストロゲン受容 体との親和性を Receptor binding assay で確認するととも に，エストロゲンに感受性を持つ MCF-7 細胞株を用いて 細胞增殖試験 (E-screen)を実施した.また，メトキシクロー ルのエストロゲン様作用をin vivo で確認するため, 卵巣を 摘出したラットを用いて Uterotrophic assay を実施した.

Receptor binding assay では, メトキシクロールには $10^{-5}$ M で，その代謝産物である HPTEには $10^{-6} \mathrm{M}$ 以上で，それ ぞれエストロゲン受容体との親和性が観察された。また, E-screen では, これらの化合物に細胞増殖活性が認められ た(図 3).Uterotrophic assay では，メトキシクロールを経 口投与した場合に明瞭な子宮増殖作用が観察された（図 4).これらの実験結果はいずれもメトキシクロールとその 代謝産物である HPTE にエストロゲン様作用があること を意味するものであることから，2世代試験でみられた生 
表 5 p,p’-DDT を用いた一連の試験結果

\begin{tabular}{ll}
\hline 試験の種類 & 結果 \\
\hline In vitro 試験 & \\
ER binding assay & 受容体との親和性 $:+$ \\
E-screen & 細胞增殖活性 $:++$ \\
In vivo 試験 & エストロゲン様作用/抗エストロゲン様作用 $:-$ \\
Uterotrophic assay & アンドロゲン様作用/抗アンドロゲン様作用 $:-$ \\
Hershberger assay & ホルモンバランスの変化, 肝重量増加 \\
Enhanced TG 407 & 催奇形性 : - \\
催奇形性試験 & ホルモンバランスの変化, 肝重量増加 \\
2 世代繁殖試験 & 繁殖毒性 $:-$ \\
\hline
\end{tabular}

殖毒性がメトキシクロールまたは HPTEのエストロゲン 様作用に基づくものであることが示唆される.したがって, メトキシクロールには内分泌攪乱作用があるものと判断さ れる。

一方, p,p'-DDTについては, in vitro でエストロゲン様作 用が報告されており ${ }^{10)}$ ，さらに代謝産物である $\mathrm{p}, \mathrm{p}$-DDE には抗アンドロゲン様作用が指摘されている ${ }^{11}$. 我々の実 験でも, in vitro ではエストロゲン様作用のあることが確認 された(表 5). しかし，一連の in vivo 試験では性ホルモン の不均衡（エストロゲン濃度の低下とプロゲステロン濃度 の上昇）がみられたものの，催奇形性および繁殖毒性につ いてはいずれも院性の結果を得た。これらの結果から, p,p'DDT には in vitro でエストロゲン様作用があり, in vivo で は動物のホルモン合成・代謝系に影響を及ぼす内分泌活性 物質であるが明らかとなった。しかし，これらの作用に基 づく明らかな毒性は調べた範囲では認められなかったこと から, 現時点では内分泌攪乱性は確認されるに至っていな w.

\section{おわりに}

以上に述べた如く, 農薬の七トに対する影響については， 最新のガイドラインに示された方法に沿って幾つかの指標 を追加した 2 世代繁殖試験や催奇形性試験を実施し, 何ら かの生殖・発生毒性が観察された場合には一連の方法でそ の機序を調べることにより, 少なくともエストロゲン様作 用に基づく内分泌攪乱作用の有無は予测できると考えられ る.また，抗アンドロゲン様作用に基づく内分泌攪乱作用 についても，その検出にこれらの試験が有効であることが 示されている ${ }^{11,12)}$. したがって, 発癌性を含めた一連の試験 が要求されている農薬については, それらが最新の方法に したがって適切に実施され，かつ陰性の結果が得られてい る限り, 内分泌攪乱性について重大な見落としは生じない と考えられる。一方，一連の試験で内分泌系に対する作用 が疑われた場合や, 試験は実施されているもののその手法
が古いために必ずしもすべての生殖・発生毒性が精査され ていない場合は，ここで述べたようなメカニズム解析を実 施するなどして，さらなる安全性の担保が必要となろう。

野生生物に対する影響に関しては，現在のところ，残念 ながらヒトに対する影響評価と比較すると極めて手薄であ ると言わざるを得ない。これらの点に関しては，今後の課 題として取り組んでいかねばならないであろう。

\section{引用 文 献}

1) Endocrine Disruptor Screening and Testing Advisory Committee: Final report, Vol. I, 1998

2) Environment Directorate, Organization for Economic Cooperation and Development: Detailed review paper, "Appraisal of test methods for sex hormone disrupting chemicals," 2001

3）宮本純之監訳：エンドクリン白書, 化学工業日報社, 1999

4) 内分泌かく乱化学物質問題の現状と今後の取り組み, 厚生 省生活衛生局食品化学課監修, 厚健出版株式会社, 1998

5) 青山博昭：農薬学事典, 朝倉書店, pp. 387-400, 2001

6) J. Kanno, L. Onyon, J. Haseman, P. Fenner-Crisp, J. Ashby \& W. Owens: Environ. Health Perspect., in press

7) 内分泌攪乱化学物質の生物試験研究法, 井上達監修, シュ プリンガー・フェアラーク東京, 2000

8) National Toxicology Program report of the endocrine disruptors low dose peer review, 2001

9) H. Tamura, S. C. Maness, K. Reischmann, D. C. Dorman, L. E. Gray, Jr. \& K. W. Gaido: Toxicol. Sci. 60, 56 (2001)

10) P. V. M. Shekhar, J. Werdell \& V. S. Basrur: J. Natl. Cancer Inst. 89, 1774 (1997)

11) W. R. Kelce, C. R. Stone, S. C. Laws, L. E. Gray, Jr., J. A. Kmppainen \& E. M. Wilson: Nature 375, 581 (1995)

12) L. E. Gray, Jr., J. S. Ostby \& W. R. Kelce: Toxicol. Appl. Pharmacol. 129, 46 (1994) 